Article

\title{
In Vitro Antioxidant Activities of Phenols and Oleanolic Acid from Mango Peel and Their Cytotoxic Effect on A549 Cell Line
}

\author{
Xuelian Bai ${ }^{1,2}$, Tongfei Lai ${ }^{1}$, Ting Zhou ${ }^{1}$, Yicong $\mathrm{Li}^{1}{ }^{1}$, Xiuting $\mathrm{Li}^{2, *}$ and Huawei Zhang ${ }^{3, *} \mathbb{D}$ \\ 1 College of Life and Environmental Sciences, Hangzhou Normal University, Hangzhou 310036, China; \\ baix12012@163.com (X.B.); laitongfei@163.com (T.L.); tingzhou@163.com (T.Z.); yicong@126.com (Y.L.) \\ 2 Beijing Advanced Innovation Center for Food Nutrition and Human Health, Beijing Technology and \\ Business University (BTBU), Beijing 10048, China \\ 3 School of Pharmaceutical Sciences, Zhejiang University of Technology, Hangzhou 310014, China \\ * Correspondence: lixt@btbu.edu.cn (X.L.); hwzhang@zjut.edu.cn (H.Z.); Tel.: +86-571-8832-0613 (H.Z.)
}

Academic Editor: Susana M. Cardoso

Received: 15 May 2018; Accepted: 7 June 2018; Published: 8 June 2018

\begin{abstract}
Mango peel, the main by-product of juice processing, possesses appreciable quantities of bioactive phenolic compounds and is worthy of further utilization. The present work reports for the first time the HPLC analysis and in vitro antioxidant evaluation of mango peel phenols (MPPs) and their cytotoxic effect on the A549 lung cancer cell line. These results indicated that mango peel has the total phenolic content of $723.2 \pm 0.93 \mathrm{mg} \cdot \mathrm{kg}^{-1}$ dry mango peel (DMP), which consisted mainly of vanillic aldehyde, caffeic acid, chlorogenic acid, gallic acid, procyanidin $\mathrm{B}_{2}$ and oleanolic acid. Antioxidant assays showed that MPPs had strong antioxidant activities, with $92 \pm 4.2 \%$ of DPPH radical scavenging rate, $79 \pm 2.5 \%$ of ABTS radical inhibition rate and $4.7 \pm 0.5 \mu \mathrm{M}$ Trolox equivalents per $\mathrm{kg}^{-1}$ DMP of ferric reducing power. Gallic acid possess a stronger antioxidant capacity than other phenols. In vitro cytotoxic tests suggested that mango peel extract (MPE) had an $\mathrm{IC}_{50}$ value of $15 \mathrm{mg} \cdot \mathrm{mL}^{-1}$ and MPPs had a stronger inhibitory effect on the A549 cell line. Oleanolic acid exhibited the strongest cytotoxicity, with an $\mathrm{IC}_{50}$ value of $4.7 \mu \mathrm{M}$, which was similar with that of the positive control 5-fluorouracil.
\end{abstract}

Keywords: mango peel; phenol; antioxidant effect; cytotoxic activity

\section{Introduction}

Mango is one of the most popular fruits, with high nutrition and commodity value, which is grown in over 70 countries in the world and includes about 35 species, including Mangifera altissima, M. applanata, M. indica, etc., which M. indica L. is one of the most cultivated varieties. As of 2005, China has been listed as the second largest producer of mango, with $12.9 \%$ of the world's output. Mango fruit is suitable for not only fresh eating, but also processing into juices, chutneys, sauces and preserved fruit. Worldwide this accounts for about $25 \%$ of mango production. However, the large amount of by-products, like mango skins mango seeds (representing 20 to $40 \%$ of the total mass), causes environmental pollution [1]. Recently, some researchers discovered that mango (M. indica) peel is a rich source of phenolic compounds, with amounts up to $0.55 \sim 1.1 \mathrm{~g} \cdot \mathrm{kg}^{-1}$ dry mango peel (DMP) [2,3]. Although many studies had been carried out on extraction and purification of mango phenols [4-9], few have reported on the compositional analysis, antioxidant and cytotoxic effects of mango peel phenols (MPPs). The present work is the first to describe an evaluation of the in vitro antioxidant activities of mango (M. indica L.) peel extract (MPE) and its MPPs, including DPPH•, 
ABTS•+ and FRAP scavenging, as well as their cytotoxic effect on the A549 human lung carcinoma cell line.

\section{Results and Discussion}

\subsection{Total Phenolic Content and HPLC Analysis}

Using the modified Folin-Ciocalteu method, the total phenolic content was determined to be $723.2 \pm 0.93 \mathrm{mg} \cdot \mathrm{kg}^{-1} \mathrm{DMP}$ in MPE of M. indica L. As shown in Figure 1, five phenolic compounds were detected in MPE, including vanillic aldehyde (A), caffeic acid (B), chlorogenic acid (D), gallic acid (E), procyanidin $B_{2}(\mathbf{F})$ together with oleanolic acid (C) (Figure 2). Quantitative analysis showed that mango peel had the highest content of chlorogenic acid $\left(19.8 \pm 0.31 \mathrm{mg} \cdot \mathrm{kg}^{-1}\right)$ followed by procyanidin $\mathrm{B}_{2}\left(12.5 \pm 0.61 \mathrm{mg} \cdot \mathrm{kg}^{-1}\right)$, caffeic acid $\left(11.4 \pm 0.08 \mathrm{mg} \cdot \mathrm{kg}^{-1}\right)$, gallic acid $\left(7.0 \pm 0.57 \mathrm{mg} \cdot \mathrm{kg}^{-1}\right)$, oleanolic acid $\left(3.0 \pm 0.25 \mathrm{mg} \cdot \mathrm{kg}^{-1}\right)$, vanillic aldehyde $\left(0.55 \pm 0.04 \mathrm{mg} \cdot \mathrm{kg}^{-1}\right)$.

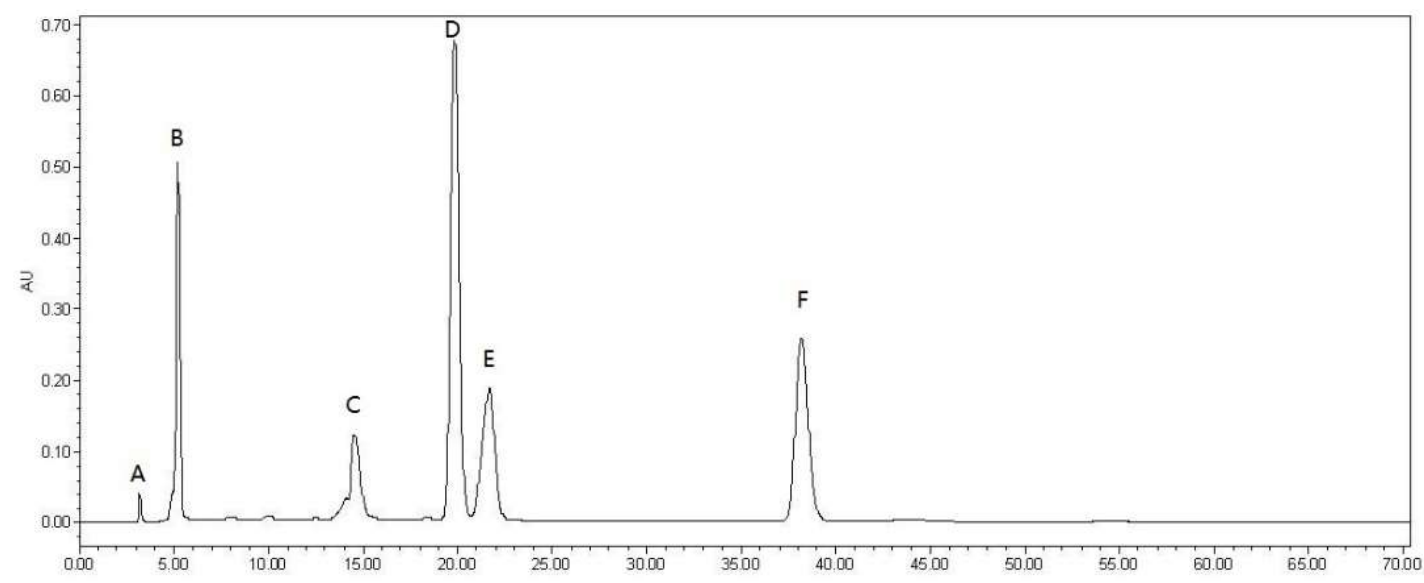

Figure 1. HPLC chromatography profile of mango peel extract (MPE). (A-vanillic aldehyde; B-caffeic acid; C-oleanolic acid; D-chlorogenic acid; E-gallic acid; F-procyanidin $\left.\mathrm{B}_{2}\right)$.<smiles>COc1cc(C=O)ccc1O</smiles>

(A)<smiles>O=C(O)C=Cc1ccc(O)c(O)c1</smiles>

(B)

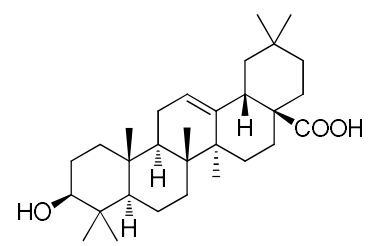

(C)<smiles>O=C(/C=C/c1ccc(O)c(O)c1)O[C@H]1C[C@](O)(C(=O)O)C[C@H](O)[C@H]1O</smiles>

(D)<smiles>O=C(O)c1cc(O)c(O)c(O)c1</smiles>

(E)<smiles>Oc1cc(O)c2c(c1)O[C@H](c1ccc(O)c(O)c1)C(O)C2c1c(O)cc(O)c2c1O[C@H](c1ccc(O)c(O)c1)[C@H](O)C2</smiles>

(F)

Figure 2. Chemical structures of detected compounds in MPE. (A-vanillic aldehyde; B-caffeic acid; C-oleanolic acid; D-chlorogenic acid; E-gallic acid; F-procyanidin $\mathrm{B}_{2}$ ).

\subsection{Antioxidant Activity of MPE and MPPS}

An in vitro antioxidant assay indicated that MPE had strong capacity of scavenging DPPH and ABTS radicals and ferric reducing power at $2.0 \mathrm{mg} \cdot \mathrm{mL}^{-1}$, which were $92 \pm 4.2 \%, 79 \pm 2.5 \%$, 
$4.7 \pm 0.53 \mu \mathrm{mol} \mathrm{TE} \cdot \mathrm{kg}^{-1} \mathrm{DMP}$, respectively. In order to identify the potential contributor(s) in MPE, six detected phenolic compounds were further evaluated their antioxidant effects. As shown in Table 1, these MPPs and oleanolic acid exhibited different antioxidant capacity at $100 \mu \mathrm{M}$. Especially, gallic acid possessed the strongest DPPH• scavenging rate $(97 \pm 0.4 \%)$, ABTS $\bullet+$ inhibition rate $(86 \pm 3.0 \%)$ and reducing power $\left(12 \pm 0.5 \mu \mathrm{mol} \mathrm{TE} \cdot \mathrm{kg}^{-1} \mathrm{DMP}\right)$, which was consistent with the findings revealed by Yen and his coworkers [10]. The antioxidant activity of oleanolic acid was weaker than that of any of the other chemical constituents in MPE, with $2.7 \pm 0.17 \%$ of DPPH• scavenging rate, $11 \pm 1.5 \%$ of $\mathrm{ABTS} \bullet+$ inhibition rate and $1.2 \pm 0.09 \mu \mathrm{mol} \mathrm{TE} \cdot \mathrm{kg}^{-1} \mathrm{DMP}$ of reducing power.

Table 1. Antioxidant activity of six phenol compounds $(n=3)$.

\begin{tabular}{|c|c|c|c|}
\hline \multirow{2}{*}{ Phenol } & \multicolumn{3}{|c|}{ Antioxidant Activity } \\
\hline & DPPH• Scavenging Rate (\%) & ABTS• + Inhibition Rate (\%) & FRAP Assay $\left(\mathrm{TE}, \mu \mathrm{mol} \cdot \mathrm{kg}^{-1}\right)$ \\
\hline A & $60 \pm 1.0$ & $80 \pm 3.2$ & $8.0 \pm 0.96$ \\
\hline B & $29 \pm 1.0$ & $55 \pm 4.5$ & $6.0 \pm 0.65$ \\
\hline $\mathrm{C}$ & $2.7 \pm 0.17$ & $11 \pm 1.5$ & $1.2 \pm 0.09$ \\
\hline D & $80 \pm 1.2$ & $76 \pm 3.6$ & $8.0 \pm 0.25$ \\
\hline $\mathrm{E}$ & $97 \pm 0.4$ & $86 \pm 3.0$ & $12 \pm 0.52$ \\
\hline $\mathbf{F}$ & $78 \pm 1.2$ & $76 \pm 2.4$ & $8.0 \pm 0.22$ \\
\hline $\mathrm{MPE} *$ & $92 \pm 4.2$ & $79 \pm 2.5$ & $4.7 \pm 0.53$ \\
\hline
\end{tabular}

(A-vanillic aldehyde, B-caffeic acid, C—oleanolic acid, D-chlorogenic acid, E-gallic acid, $\mathbf{F}-$ procyanidin $\mathrm{B}_{2}$, G-5-fluorouracil, MPE-mango peel extract) * at $2.0 \mathrm{mg} \cdot \mathrm{mL}^{-1}$.

\subsection{Cytotoxic Effect of $M P E$ and $M P P S$}

As shown in Table 2, MPE exhibited in vitro weak cytotoxic activity against A549 lung cancer cells, with an $\mathrm{IC}_{50}$ value of $15 \mathrm{mg} \cdot \mathrm{mL}^{-1}$, while caffeic acid, oleanolic acid, chlorogenic acid and procyanidin $\mathrm{B}_{2}$ had potent inhibitory effects. Among these MPPs, oleanolic acid had the strongest cytotoxic effect, with an $\mathrm{IC}_{50}$ value of $4.7 \mu \mathrm{M}$, which was similar to that of the positive control 5-fluorouracil $(3.8 \mu \mathrm{M})$.

Table 2. In vitro cytotoxic effect of MPE, MPPs and oleanolic acid on A549 cells.

\begin{tabular}{ccccccccc}
\hline & A & B & C & D & E & F & G & MPE \\
\hline IC $_{50}$ value $(\mu \mathrm{M})$ & 7.2 & 8.9 & 4.7 & 9.8 & 51.8 & 14.3 & 3.8 & $15 \mathrm{mg} \cdot \mathrm{mL}^{-1}$ \\
\hline
\end{tabular}

(A-vanillic aldehyde, B-caffeic acid, C-oleanolic acid, D-chlorogenic acid, E-gallic acid, F-procyanidin $\mathrm{B}_{2}$, G-5-fluorouracil, MPE-mango peel extract).

These findings were consistent with the morphological variations of the nucleus of A549 cells observed using 4',6-diamidino-2-phenylindole (DAPI) staining. As shown in Figure 3, the nucleus showed weak blue fluorescence when A549 cells were treated with caffeic acid, oleanolic acid and chlorogenic acid, which suggested that these chemicals had significant in vitro cytotoxic effects. However, the strong fluorescence of the nucleus treated with MPE and gallic acid indicated they had weak antiproliferative activity. 

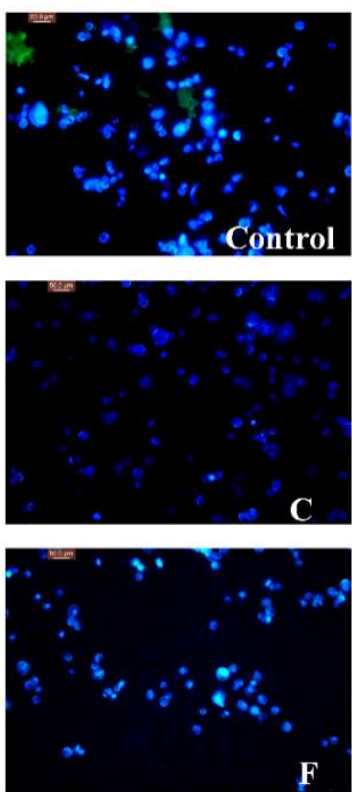
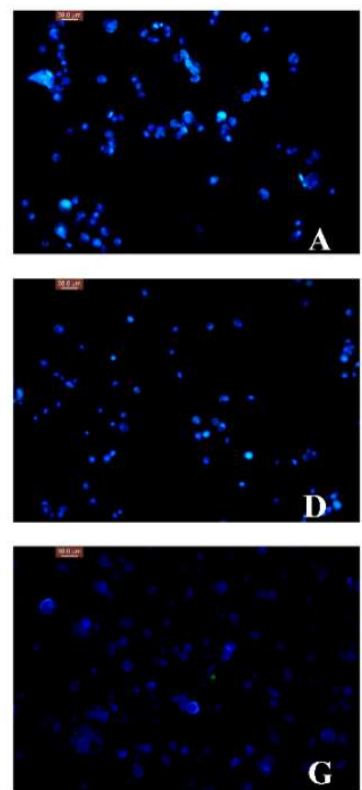
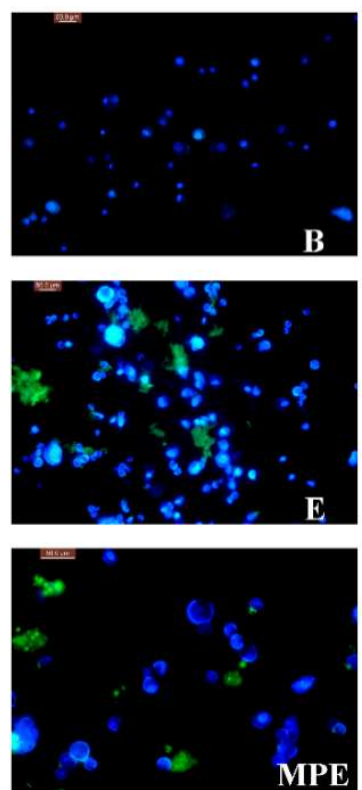

Figure 3. Fluorescence microscopy of A549 cell line treated with MPE, MPPs and oleanolic acid. (Control-untreated, A-vanillic aldehyde, B-caffeic acid, C-oleanolic acid, D-chlorogenic acid, E-gallic acid, F-procyanidin $\mathrm{B}_{2}, \mathrm{G}-5$-fluorouracil, MPE-mango peel extract).

\section{Experimental Section}

\subsection{Determination of Total Phenolic Content}

Fresh mango (M. indica L.) was purchased from a fruit market in Hangzhou (China). After peeling, lyophilizing and grinding, about $20 \mathrm{~g}$ of DMP powder was extracted with $200 \mathrm{~mL}$ of $70 \%$ aqueous ethanol $\left(50^{\circ} \mathrm{C}\right)$ under stirring for 20 min using microwave-assisted extraction (MAS-I, Xinyi Microwave Equipment Co., Ltd, Shanghai, China). The obtained MPE was concentrated under reduced pressure and lyophilized (LGJ-10N, Beijing Yaxing Instrument Co., Ltd., Beijing, China). After redissolving in $500 \mathrm{~mL}$ of $20 \%$ ethanol solution, the resulting extract was centrifuged for $15 \mathrm{~min}$ at $60,000 \times g$ (CR21GII, Hitachi Koki Co., Ltd., Tsuen Wan, Japan) and retained on a normal atmosphere column with $200 \mathrm{~mL}$ macroporous absorbent resin XAD-16 (Rohm and Haas, Philadelphia, PA, USA) followed by eluting with three bed volumes of $80 \%$ alcohol in $\mathrm{H}_{2} \mathrm{O}$. The collected elution was concentrated under reduced pressure and lyophilised. The afforded phenol-enriched extract was dissolved in methanol with a final concentration of $20 \mathrm{mg} \cdot \mathrm{mL}^{-1}$ and preserved at $4^{\circ} \mathrm{C}$ before HPLC analysis. The total phenolic content of MPE was determined by the modified Folin-Ciocalteu method proposed by Wijngaard and Brunton [11]. Triplicate tests were conducted for each sample. The result was expressed as gram of gallic acid equivalents per kilogram of DMP (g GAE $\left.\cdot \mathrm{kg}^{-1} \mathrm{DMP}\right)$.

\subsection{HPLC Analysis of MPPs and Oleanolic Acid}

Five phenolic compounds, vanillic aldehyde, caffeic acid, chlorogenic acid, gallicacid, procyanidin $\mathrm{B}_{2}$, and oleanolic acid (Figure 2), and 5-fluorouracil were purchased from Sigma-Aldrich Chemical (St. Louis, MO, USA) and respectively dissolved in methanol to a final concentration of $100 \mu \mathrm{M}$. HPLC analysis of MPPs was performed using a HPLC system (Shimadzu, Toyko, Japan) equipped with a SIL-10AF autosampler, a CTO-10AS column oven $\left(25^{\circ} \mathrm{C}\right)$ and a SPD-10AV UV-visible detector on a reversed-phase SunFire C8 $(250 \mathrm{~mm} \times 4.6 \mathrm{~mm}$, ID $5 \mu \mathrm{m})$ column (Waters, Milford, MA) under an isocratic condition of $10 \%$ acetonitrile in $\mathrm{H}_{2} \mathrm{O}$ with $0.1 \%$ acetic acid at $1.0 \mathrm{~mL} \cdot \mathrm{min}^{-1}$ and $280 \mathrm{~nm}$. All solvents were filtered with a $0.22 \mu \mathrm{m}$ membrane filter and each injection volume was $10 \mu \mathrm{L}$. Quantitative analysis of MPPs and oleanolic acid was carried out using the external standard method 
described before [12]. Triplicate tests were conducted for each sample. The level of each compound was expressed in $\mathrm{mg} \cdot \mathrm{kg}^{-1} \mathrm{DMP}$.

\subsection{Antioxidant Assay of MPPs}

\subsubsection{DPPH Assay}

MPP $(100 \mu \mathrm{L})$ or oleanolic acid $(100 \mu \mathrm{M})$ or MPE $\left(2.0 \mathrm{mg} \cdot \mathrm{mL}^{-1}\right)$ solution were mixed with $2 \mathrm{~mL}$ of 2,2-diphenyl-1-picrylhydrazyl radicals (DPPH, Sigma-Aldrich, $0.1 \mathrm{mM}$ in methanol). The reaction mixture was shaken vigorously and stored in the dark for $30 \mathrm{~min}$ at room temperature. The absorbance of the solution was then recorded on a Hitachi-UV-3000 spectrophotometer (Hitachi, Tokyo, Japan) at $517 \mathrm{~nm} .100 \mu \mathrm{L}$ of methanol was added to the DPPH solution used as a blank control. All measurements were performed in triplicate. The percentage scavenging effect was calculated as follows:

$$
I_{D P P H}=\frac{A_{0}-A_{1}}{A_{0}} \times 100 \%
$$

where $I_{D P P H}$ is the DPPH radical scavenging rate (\%), $A_{0}$ is the absorbance of a negative control, $A_{1}$ is the absorbance of each sample [13].

\subsubsection{ABTS Assay}

The capability of scavenging 2,2'-azinobis(3-ethylbenzothiaziline-6-sulfonate radical (ABTS, Sigma-Aldrich) radical was carried out according to the method described by Bao and his co-workers [14]. The ABTS radical was prepared by mixing equal volumes of $7 \mathrm{mM}$ aqueous ABTS and $2.45 \mathrm{mM}$ aqueous potassium persulfate. The solution was kept in the dark at room temperature for $16 \mathrm{~h}$ before use. The absorbance of ABTS radical solution at $734 \mathrm{~nm}$ was adjusted to 0.7 by dilution with distilled water. $1 \mathrm{~mL}$ of fresh ABTS•+ solution was added to $10 \mathrm{~mL}$ sample solution or methanol (negative control), and stored at room temperature for $6 \mathrm{~min}$. The absorbance of the reaction mixed solution was immediately measured at $734 \mathrm{~nm}$. All measurements were run in triplicate. The percentage decrease of the absorbance at $734 \mathrm{~nm}$ was calculated by the formula:

$$
I_{A B T S}=\left[\frac{A_{0}-A_{1}}{A_{0}}\right] \times 100 \%
$$

where $I_{A B T S}$ is the ABTS $\bullet+$ inhibition rate $(\%), A_{0}$ is the absorbance of a negative control, $A_{1}$ is the absorbance of each chemical $(100 \mu \mathrm{M})$ or MPE $\left(2.0 \mathrm{mg} \cdot \mathrm{mL}^{-1}\right)$ solution.

\subsubsection{FRAP Assay}

Fresh FRAP reagent was prepared by mixing $2.5 \mathrm{~mL}$ of tripyridine triazine (TPTZ, Sigma-Aldrich, $10 \mathrm{mM}$ in $40 \mathrm{mM} \mathrm{HCl}), 2.5 \mathrm{~mL}$ of ferric chloride $(20 \mathrm{mM})$ and $25 \mathrm{~mL}$ of sodium acetate buffer $(300 \mathrm{mM}$, pH 3.6). $900 \mu \mathrm{L}$ of the FRAP reagent were mixed with $300 \mu \mathrm{L}$ of each phenol $(100 \mu \mathrm{M})$ or MPE $\left(2.0 \mathrm{mg} \cdot \mathrm{mL}^{-1}\right)$ solution or methanol (negative control) in $1 \mathrm{~cm}$ disposable plastic cells and incubated at $37^{\circ} \mathrm{C}$ for $120 \mathrm{~min}$. The absorbance was taken on a Hitachi-UV-3000 spectrophotometer at $595 \mathrm{~nm}$. A standard curve was obtained using Trolox solution at 0.5, 1.0, 1.5, $2.0 \mathrm{mM}$. The absorbance of each sample was compared with that of the Trolox standard and the results were expressed in terms of micromole Trolox equivalents per $\mathrm{kg}$ DMP $\left(\mu \mathrm{M}\right.$ TE $\left.\cdot \mathrm{kg}^{-1} \mathrm{DMP}\right)$. All measurements were performed in triplicate. The ferric reducing power was calculated by the following equation:

$$
I_{F R A P}=\frac{A_{1}}{A_{0}} \times 100 \%
$$

where $I_{F R A P}$ is the ferric reducing power, $A_{0}$ is the absorbance of a negative control, $A_{1}$ is the absorbance in the presence of a tested sample [15]. 


\subsection{Cytotoxic Effect of MPPs and Oleanolic Acid on the A549 Cell Line}

\subsubsection{Inhibitory Activity}

Human NSCLC cell lines A549 were obtained from the Cancer Institute of Sun Yat-Sen University (Guangzhou, China) and cultured in RPMI-1640 (Sangon Biotech Co., Ltd., Shanghai, China) medium containing 10\% FBS (Sangon Biotech Co., Ltd.) and 1\% (0.01 g. $\left.\mathrm{mL}^{-1}\right)$ penicillin-streptomycin (Sigma-Aldrich, St. Louis, MO, USA) at $37{ }^{\circ} \mathrm{C}$ in a humidified $5 \% \mathrm{CO}_{2}$ incubator (Chengdu Must Bio-Technology Co., Ltd., Chengdu, China). The medium was changed daily and subcultured when they reached a confluence of $80 \%$.

Six chemicals including vanillic aldehyde, caffeic acid, oleanolic acid, chlorogenic acid, gallic acid and anthocyanidin $\mathrm{B}_{2}$ were dissolved in $500 \mu \mathrm{L}$ DMSO solution, filtered by the filter membrane of $0.22 \mu \mathrm{m}$. These solutions were diluted with liquid containing 10\% fetal bovine serum RPMI-1640 (Sangon Biotech Co., Ltd.) culture resulting in final concentrations of 6.25, 12.5, 25, 50, 75, 100, 150, $200 \mu \mathrm{M}$, respectively. MPPs and oleanolic acid were also dissolved in accordance with the above methods in final concentrations of $68.5,100,200,300,400$, and $500 \mu \mathrm{g} \cdot \mathrm{mL}^{-1}$, with 5-fluorouracil as the positive control.

The effect of MPPs and oleanolic acid on cell proliferation of A549 was evaluated by cell counting kit-8 (CCK-8) assay according to the manufacturer's instruction. Briefly, cells in 96-well plates at a density of $5 \times 10^{3}$ per well were incubated for $24 \mathrm{~h}$ at $37^{\circ} \mathrm{C}$. Then the supernatant was removed and the cells were treated for $24 \mathrm{~h}$ with chemicals at different concentrations $(6.25,12.5,25,50,75,100,150$, $200 \mu \mathrm{M})$ or MPPs at different concentrations $\left(68.5,100,200,300,400\right.$, and $\left.500 \mu \mathrm{g} \cdot \mathrm{mL}^{-1}\right)$. CCK-8 $(10 \mu \mathrm{L})$ dissolved in PBS ( $5 \mathrm{mg} \cdot \mathrm{mL}^{-1}$ ) was added to each well, and the cells were further incubated for $45 \mathrm{~min}$. Finally, the medium containing CCK-8 was removed and $100 \mu \mathrm{L}$ of DMSO was added to each well. The plate was gently shaken for $10 \mathrm{~min}$ to dissolve the formazan crystals (Sangon Biotech Co., Ltd.) and the absorbance was measured at $450 \mathrm{~nm}$ on a ELISA (Thermo Electron Co., Vantaa, Finland). The percentage viability was calculated using the following formula:

$$
I C=\left[1-\frac{O D_{\text {sample }}-O D_{\text {blank }}}{O D_{\text {negative }}-O D_{\text {blank }}}\right] \times 100 \%
$$

Sample group $(90 \mu \mathrm{L}$ cell suspension $+10 \mu \mathrm{L}$ phenols solution $+10 \mu \mathrm{L}$ CCK-8 reagent (Sangon Biotech Co., Ltd.), blank group $(90 \mu \mathrm{L}$ cell medium $+10 \mu \mathrm{L}$ sample solution $+10 \mu \mathrm{L}$ CCK-8 reagent), negative groups $(90 \mu \mathrm{L}$ cell suspension $+10 \mu \mathrm{L}$ cell medium $+10 \mu \mathrm{L}$ CCK-8 reagent). The concentration of MPPs and oleanolic acid needed to inhibit cell growth by $50 \%\left(\mathrm{IC}_{50}\right)$ was calculated from the dose response curves for each cell line [16].

\subsubsection{Morphological Observation of the Nucleus of Lung Cancer A549 Cells}

The logarithmic phase of A549 cells, using $0.25 \%$ of trypsin digestion, counting, add broth, made $5 \times 10^{4} / \mathrm{mL}$ cells suspension, vaccination in culture bottle, set up the experimental group and positive control group and blank group, respectively. Each sample was incubated at $37^{\circ} \mathrm{C}$ for $24 \mathrm{~h}$ to join testing solution $(100 \mu \mathrm{M}) 1 \mathrm{~mL}$ and MPPs and oleanolic acid $\left(100 \mu \mathrm{g} \cdot \mathrm{mL}^{-1}\right)$, 5-fluorouracil $(100 \mu \mathrm{M}$, Sigma-Aldrich) as the positive control group and blank group, added $1 \mathrm{~mL}$ cultures and incubated at $37^{\circ} \mathrm{C}$ for $48 \mathrm{~h}[17,18]$. The experimental group, positive control group and blank group of medium, with sterile PBS washing, with trypsin digestion cells, using RPMI 1640 culture medium containing $10 \%$ fetal bovine serum termination of digestion, made the cell suspension, the cell suspension put in centrifuge tube, $1000 \mathrm{r} / \mathrm{min}$, the centrifugal $5 \mathrm{~min}$, abandon supernatant. Plus $5 \mu \mathrm{L}$ DAPI $\left(0.2 \mathrm{mg} \cdot \mathrm{mL}^{-1}\right)$ (Sigma-Aldrich) and kept in dark at $37^{\circ} \mathrm{C}$ for $30 \mathrm{~min}$, after the incubation, washing with buffer, add $1 \mathrm{~mL}$ culture, in the inverted fluorescence microscope observed under fluorescent green fluorescence set (Olympus Co., Tokyo, Japan) and take photos, and use the Image-ProPlus 
5.1 software (Media Cybernetics, Rockville, MD, USA) processing images, green fluorescence intensity ratio calculation $[19,20]$.

\subsection{Statistical Analysis}

All data were expressed as mean \pm standard deviation (SD) and analyzed by SPSS software (Version 19.0, Chicago, CA, USA). Values of $p<0.05$ were considered significant.

\section{Conclusions}

The present work firstly reported on in vitro antioxidant activities of phenols and oleanolic acid from mango peel and their cytotoxic effect on the A549 cell line. The ethanolic extract of mango peel is rich in phenolic compounds. HPLC analysis indicated that MPE had five main chemical constituents, including vanillic aldehyde, caffeic acid, chlorogenic acid, gallic acid, procyanidin $\mathrm{B}_{2}$ and oleanolic acid. Antioxidant assays suggested that MPE had strong DPPH and ABTS radical scavenging capacity and ferric reducing power at $2.0 \mathrm{mg} \cdot \mathrm{mL}^{-1}$. Gallic acid possessed the strongest DPPH• scavenging rate $(97 \pm 0.4 \%)$, ABTS $\bullet+$ inhibition rate $(86 \pm 3.0 \%)$ and reducing power $(12 \pm 0.5) \mu \mathrm{mol} \mathrm{TE} \cdot \mathrm{kg}^{-1}$ DMP. In vitro CCK-8 assay indicated that oleanolic acid exhibited the strongest inhibitory effect on A549 cell line with an $\mathrm{IC}_{50}$ value of $(4.71 \pm 0.30 \mu \mathrm{M})$. Fluorescence staining experiments confirmed that oleanolic acid inhibited cell proliferation by destroying the nucleus of A549 cell. These findings would promote the utilization of mango peel and the development of antioxidant food.

Author Contributions: X.B. wrote the paper and analyzed the data; T.L., T.Z. and Y.L. performed all the experiments; X.L. and H.Z. designed the experiment and made valuable revision.

Funding: Financial supports for this project from Beijing Advanced Innovation Center for Food Nutrition and Human Health, Beijing Technology and Business University (BTBU) was gratefully appreciated.

Conflicts of Interest: The authors declare no conflict of interest.

\section{References}

1. Kaur, B.; Srivastav, P.P. Effect of cryogenic grinding on chemical and morphological characteristics of mango (Mangifera indica L.) peel powder. J. Food Process. Pres. 2018, 42, e13583. [CrossRef]

2. Ndoye, S.F.; Fraisse, D.; Akendengue, B.; Dioum, M.D.; Gueye, R.S.; Sall, C.; Seck, I.; Felgines, C.; Seck, M.; Senejoux, F. Antioxidant and antiglycation properties of two mango (Mangifera indica L.) cultivars from Senegal. Asian Pac. J. Trop. Biomed. 2018, 3, 137-141.

3. Fernandez-Ponce, M.T.; Casas, L.; Mantell, C.; De la Ossa, E.M. Use of high pressure techniques to produce Mangifera indica L. leaf extracts enriched in potent antioxidant phenolic compounds. Innov. Food Sci. Emerg. 2015, 29, 94-106. [CrossRef]

4. Pierson, J.T.; Monteith, G.R.; Roberts-Thomson, S.J.; Dietzgen, R.G.; Gidley, M.J.; Shaw, P.N. Phytochemical extraction, characterisation and comparative distribution across four mango (Mangifera indica L.) fruit varieties. Food Chem. 2014, 149, 253-263. [CrossRef] [PubMed]

5. Zhang, D.; Wang, C.T.; Shen, L.Q.; Shin, H.C.; Lee, K.B.; Ji, B.P. Comparative analysis of oxidative mechanisms of phloroglucinol and dieckol by electrochemical, spectroscopic, cellular and computational methods. RSC Adv. 2018, 8, 1963-1972. [CrossRef]

6. Sui, X.N.; Sun, H.N.; Qi, B.K.; Zhang, M.; Li, Y.; Jiang, L.Z. Functional and conformational changes to soy proteins accompanying anthocyanins: Focus on covalent and non-covalent interactions. Food Chem. 2018, 245, 871-878. [CrossRef] [PubMed]

7. Pacheco-Ordaz, R.; Antunes-Ricardo, M.; Gutierrez-Uribe, J.A.; Gonzalez-Aguilar, G.A. Intestinal permeability and cellular antioxidant activity of phenolic compounds from mango (Mangifera indica cv. Ataulfo) peels. Int. J. Mol. Sci. 2018, 19, 514. [CrossRef] [PubMed]

8. Suvarnakuta, P.; Chaweerungrat, C.; Devahastin, S. Effects of drying methods on assay and antioxidant activity of xanthones in mangosteen rind. Food Chem. 2011, 125, 240-247. [CrossRef] 
9. Hu, K.; Dars, A.G.; Liu, Q.D.; Xie, B.J.; Sun, Z.D. Phytochemical profiling of the ripening of Chinese mango (Mangifera indica L.) cultivars by real-time monitoring using UPLC-ESI-QTOF-MS and its potential benefits as prebiotic ingredients. Food Chem. 2018, 256, 171-180. [CrossRef] [PubMed]

10. Yen, G.C.; Duh, P.D.; Tsai, H.L. Antioxidant and pro-oxidant properities of ascorbic acid and gallic acid. Food Chem. 2002, 79, 307-313. [CrossRef]

11. Wijngaard, H.H.; Brunton, N. The optimisation of solid-liquid extraction of antioxidants from apple pomace by response surface methodology. J. Food Eng. 2010, 96, 134-140. [CrossRef]

12. Bai, X.L.; Yue, T.L.; Yuan, Y.H.; Zhang, H.W. Optimization of microwave-assisted extraction of polyphenols from apple pomace. J. Sep. Sci. 2010, 33, 3571-3578. [CrossRef] [PubMed]

13. Lily, Z.P.A.; Rokiah, H.; Shaida, F.S.; Ahmed, Y.C.; Othman, S.; Fumio, K.; Kushairi, M.S. In vitro antioxidant and antidiabetic activites of Gluta torquata. Ind. Crop Prod. 2015, 76, 755-760.

14. Bao, Y.T.; Qu, Y.; Li, J.H.; Li, Y.F.; Ren, X.D.; Maffucci, K.G.; Li, R.P.; Wang, Z.G.; Zeng, R. In vitro and in vivo antioxidant activities of the flowers and leaves from Paeonia rockii and identification of their antioxidant constituents by UHPLC-ESI-HRMSn via pre-column DPPH reaction. Molecules 2018, 23, 392. [CrossRef] [PubMed]

15. Iris, F.F.B.; Strain, J.J. The ferric reducing ability of plasma (FRAP) as a measure of "antioxidant power": The FRAP assay. Anal. Biochem. 1996, 239, 70-76.

16. Huang, W.S.; Mao, S.Q.; Zhang, L.Q.; Lu, B.Y.; Zheng, L.F.; Zhou, F.; Zhao, Y.J.; Li, M.Q. Phenolic compounds, antioxidant potential and antiproliferative potential of 10 common edible flowers from China assessed using a simulated in vitro digestion-dialysis process combined with cellular assays. J. Sci. Food Agric. 2017, 97, 4760-4769. [CrossRef] [PubMed]

17. Wu, F.F.; Zhou, L.; Jin, W.D.; Yang, W.J.; Wang, Y.; Yan, B.; Du, W.L.; Zhang, Q.; Zhang, L.; Guo, Y.H. Anti-proliferative and apoptosis-inducing effect of theabrownin against non-small cell lung adenocarcinoma A549 cells. Front. Pharmacol. 2016, 7, 465. [CrossRef] [PubMed]

18. Wang, J.; Li, J.Z.; Lu, A.X.; Zhang, K.F.; Li, B.J. Anticancer effect of salidroside on A549 lung cancer cells through inhibition of oxidative stress and phospho-p38 expression. Oncol. Lett. 2014, 7, 1159-1164. [CrossRef] [PubMed]

19. Ramalingam, V.; Rajaram, R. Enhanced antimicrobial, antioxidant and anticancer activity of Rhizophora apiculata: An experimental report. Biotech 2018, 8, 200. [CrossRef] [PubMed]

20. Maciela, L.G.; do Carmo, M.A.V.; Azevedo, L.; Daguer, H.; Molognoni, L.; De Almeida, M.M.; Granato, D.; Rosso, N.D. Hibiscus sabdariffa anthocyanins-rich extract: Chemical stability, in vitro antioxidant and antiproliferative activities. Food Chem. Toxicol. 2018, 113, 187-197. [CrossRef] [PubMed]

Sample Availability: Samples of the compounds (vanillic aldehyde, caffeic acid, chlorogenic acid, gallic acid, procyanidin B2 and oleanolic acid) are available from the authors. 